\title{
Spore Germination, Gametophyte Development and Studies of the Growth Rate of Adiantum capillus-veneris L.
}

\author{
Fatai A. OLOYEDE*, Tosin Y. OLATUNJI, Ejeoghene R. OGBIMI \\ Obafemi Awolowo University, Faculty of Science, Department of Botany, Ede Road, Ile-Ife, \\ Nigeria; soji.oloyede@yahoo.com (*correspondingauthor); aiwoomoshehin@gmail.com; ejeayisire@yahoo.com
}

\begin{abstract}
Spore culture of Adiantum capillus-veneris was carried out with a view to massively raising new fernlets cultured in growth nutrient with agar and to study its growth rate. Petri-dishes B, C, D and E containing modified Moores nutrient were used with 'A' containing wet soil without nutrient and served as control. All the Petri-dishes were autoclaved for 15 minutes and allowed to cool before sowing sterilized spores in three replicates and maintained at $\mathrm{pH} 5.80$ and $23 \pm 2{ }^{\circ} \mathrm{C}$ with cool fluorescent white light in the incubator. Spores imbibed water from the nutrient, ruptured and germination started six days after sowing with emergence of colourless, uniseriate, elongated filamentous rhizoid. Prothallial cell which was green in colour started growing perpendicularly to the rhizoid. The germination rate was scored at an interval of four days for thirty days. Various stages of growth recorded include filamentous, spatulate, prothallus and two leaved fernlets. The heart-shaped gametophyte developed between 27-60 days with 12-16 rhizoids, archegonia and antheridia. Both archegonia and antheridia were found on each gametophyte, showing the evidence of being homosporous fern. This type of gametophyte growth and development is called Drynaria type. After 8 weeks from the transfer into the garden soil, plant height and increase in the number of leaves were observed and recorded. No growth was observed in the control showed there is need for protocol in raising massive fernlets rapidly within a short time. The study showed that $A$. capillus-veneris could be raised easily from freshly collected spores.
\end{abstract}

Keywords: conservation, endangered, fern, in vitro, nutrient, propagation, threatened

\section{Introduction}

Pteridophytes are flowerless, seedless, spore producing, vascular plants (Smith et al., 2006). There is a need for constant supply of water for sexual reproduction, to prevent and maintain fragile, delicate gametophyte stage in the life of a fern from desiccation (Oloyede and Odu, 2011). Pteridophytes depend on the microclimatic conditions of their habitats for their survival. Any kind of disturbance can hinder the evolutionary process leading to their population decline. Factors like climatic change and anthropogenic activities such as industrialization, encroachment of forest lands, over exploitation of natural resources, large scale collection of ferns from the forests by visitors and local people for ornamental and medicinal purposes, and during excursions, pose a major threat to the survival of these groups of plants (FEPA, 1991).

The genus Adiantum is well distributed worldwide, found in the tropical and warm temperate regions and usually growing in moist calcareous cliffs, river banks, edges of streams, walls of lime sinks (Jones, 1998) and slope land especially bare land. It has over 200 species spread across both Southern and Northern hemispheres (Rajkumar et al.,
2010). Adiantum capillus-veneris $\mathrm{L}$. is a small slow growing fern found throughout the whole world mostly in moist places. It is a homosporous fern because it is characterized by only one kind of spores which are morphologically similar. Spores are found inside sporangia, on the abaxial surface of the pinnae and covered by false indusia at the edge of the leaflet. Its spores are circular in shape with regulategemmate ornamentation. Its equatorial and polar views are 41.43 and $35.43 \mu \mathrm{m}$ respectively and has a cell number of annulus which ranges from 19-23 (Fahimeh et al., 2011). Spores enhance the continuity and distribution of the species because of the regenerative ability of each spore to form a new (whole) plant. Successful propagation needs proper nutrition, protection and free dispersal of the spores (Oloyede et al., 2011). It has medicinal values as hair tonic and treatment for dandruff; pinnae oils have antimicrobial activity (Victor $e$ t al., 2003).

Conventional methods for the propagation of ornamental and medicinal plants such as stem cuttings, seed sowing, suckers, tuberous roots and grafting (angiosperm); spore sowing, and division of rhizomes, and rootstocks only generate few plants and take longer time to mature. Thus, commercial availability and marketability are greatly 
558

affected. Tissue culture of plants will generate more plants from a single mother plant in a shorter period of time. In vitro regeneration has been recognized as a very useful technique for propagation and conservation of threatened plants. Mass propagation of plants through in vitro culture is one of the best and most successful options of commercial application of plant tissue culture technology. Due to the late germination of spores, slow growth rate of plantlets in their natural environment, conventional propagation methods like using spores and underground rhizome have limited scope. Regeneration through tissue culture can be applied to produce species of fern that are difficult to propagate conventionally.

Dyer (1979) reported that Pteridophyte spores are easy to obtain, stored in large quantities, and can germinate rapidly in simple media. Fern spores germination, growth, and development of resulting gametophytes in artificial media have been reported by many workers (Verma et al., 2000; Verma, 2003; Ganguly and Mukhopadhyay, 2005; Oloyede et al., 2011).

Spores offer an excellent biological system for the analysis of physiological and development criteria. Ruchi $e t$ al. (2008), Oloyede et al. (2011) and Jagadish and Joshi (2013) used nutrient with agar as culture medium to germinate spores of ferns for mass propagation.

Presently, a high number of individual researches are oriented towards the propagation of pteridophytes, with a view to conserving their diversity. Spores of members of Schizaeaceae and Adiantaceae are decidedly dormant; among the signals that have been identified in the breakage of spore dormancy, light and hormones are the principal ones (Raghavan, 1989). Micro-propagation holds significant promise for true to type, rapid and mass multiplication under disease free conditions. In vitro propagation methods are powerful tools for germplasm conservation and rapid multiplication of threatened and difficult to propagate species within a small space (Ayisire $e t$ al., 2009).

Conservation of genetic materials of many threatened medicinal plants also involves culturing techniques (Yaadwinder, 2010). From conservation point of view, ferns are becoming endangered and spores have difficulty germinating under natural conditions due to environmental factors (Baskaran and Jeyachandran, 2012). A. capillusveneris is listed as an endangered species in North Carolina and threatened in Kentucky in America (Cullina, 2008). It is also listed among the red list of threatened species (IUCN 2013; Lansdown \& Bilz, 2013) and in Nigeria, it is listed as threatened and endangered (FEPA, 1991; FNR and FNBR, 2010) species. This is because there is delay in spore germination in its natural environment. There is therefore a need for mass propagation of this economic and highly useful fern to prevent it from extinction. This is by raising new fernlets from the spores cultured in growth nutrient with agar and to study its growth rate.

\section{Materials and Methods}

Adiantum capillus-veneris L. was collected from ErinIjesa water-fall, Osun State, identified at IFE herbarium and grown as potted ornamental plant in the Department of
Botany, Obafemi Awolowo University, Ile-Ife. Mature, healthy, fertile frond was collected and used as the plant material.

Fertile fronds of $A$. capillus-veneris were wrapped in a clean white sheet of paper, placed in an envelope and kept for two weeks at room temperature for the sori to burst and the spores to be released. Spores were surface sterilized in $2 \%$ (v/v) Sodium hypochlorite solution for five minutes and rinsed thoroughly with sterilized distilled water to remove traces of disinfectant using sterilized filter paper (Dyer, 1979). The spores were air dried inside micro-flow chamber to avoid contamination and stored inside sterilized $15 \mathrm{ml}$ centrifuge tubes at $4{ }^{\circ} \mathrm{C}$ for two weeks. Five Petri-dishes labeled A, B, C, D and E were used, and $10 \mathrm{ml}$ of $0.8 \%$ hot agar was poured into four of them and allowed to cool while wet soil was used in Petri-dish A as control. All the Petridishes were autoclaved at $121{ }^{\circ} \mathrm{C}, 15 \mathrm{Ib} /$ in $^{2}$ pressure for 15 minutes before planting the spores mainly to avoid contamination. Sterilized spores were sown inside all the four Petri-dishes containing modified Moores medium (Kato, 1969) solidified by $1 \%(\mathrm{w} / \mathrm{v}$ ) agar maintained at 5.80 $\mathrm{pH}$ inside micro-flow chamber. The cultures were maintained at $23 \pm 2{ }^{\circ} \mathrm{C}$ with cool fluorescent white light intensity ca 1,000 lux, $16 \mathrm{hr} / \mathrm{d}$ in three replicates inside incubator. Fresh $4 \mathrm{ml}$ of the nutrient was added every other day throughout the experiment to each of the four Petridishes while $4 \mathrm{ml}$ of sterilized, deionized, distilled water was added to Petri-dish A containing wet soil, which served as control. In order to study the germination of the spores, growth and development of the prothalli, random samples were taken from the Petri-dishes and viewed under the Stereomicroscope inside micro-flow chamber. The germination rate was scored at an interval of four days for thirty days. Mean percentage spore germination was calculated (Mazumder et al., 2010). Photomicrographs of different stages of gametophyte developments were taken fortnightly, using a camera attached to a compound microscope. The mature gametophytes (60 days old) were removed from the medium using forceps, washed with distilled water to remove traces of agar and sown into garden soil in disposable cups. After 8 weeks of transplanting, plant height and increase in the number of leaves were observed.

\section{Results}

\section{Spore culture and spore germination}

Spores sown in agar containing modified Moores medium nutrient imbibed water from the nutrient solution and eventually ruptured. Germination (11.3-25.0\%) which was evidenced by the development of a rhizoid and prothallial cell (Plate 1 A, B, C) started between 6-10 days after sowing. The internal cell of the spore bulged out of its spore wall; chloroplasts developed and lined the cell wall inside (Plate 2). After the first ten days in culture solution, germination increased rapidly, reaching $(37.5 \%)$ on the $14^{\text {th }}$ day and a maximum of $79.91 \%$ on the $30^{\text {th }}$ day. Fig. 1 shows the result of the mean germination percentage over a period of 30 days. No gametophyte developed in the control since there was no germination of spores. The filamentous, spatulate, heart-shaped chordate and sporophytic stages were identified in the current studies. 


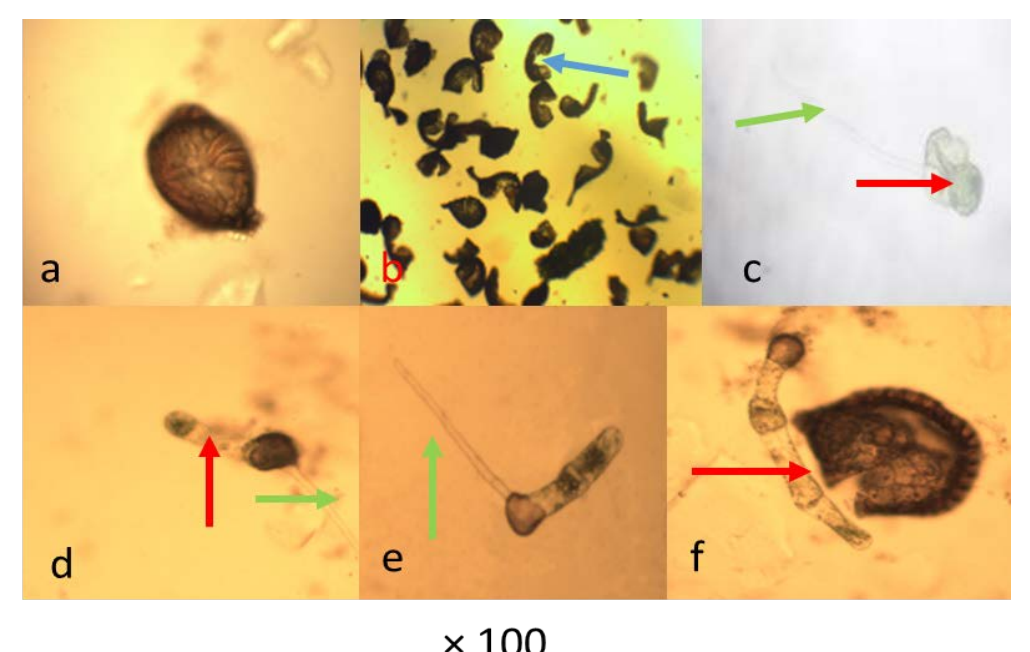

Plate 1. Initial stages of spore germination; a: spore wall intact; b: spore wall rupture; c \& d: development of prothallus (red arrow) and rhizoid (green arrow); e \& f: increase in the number of prothallial cells from two to six (red arrow) and elongation of the rhizoid (green arrow)
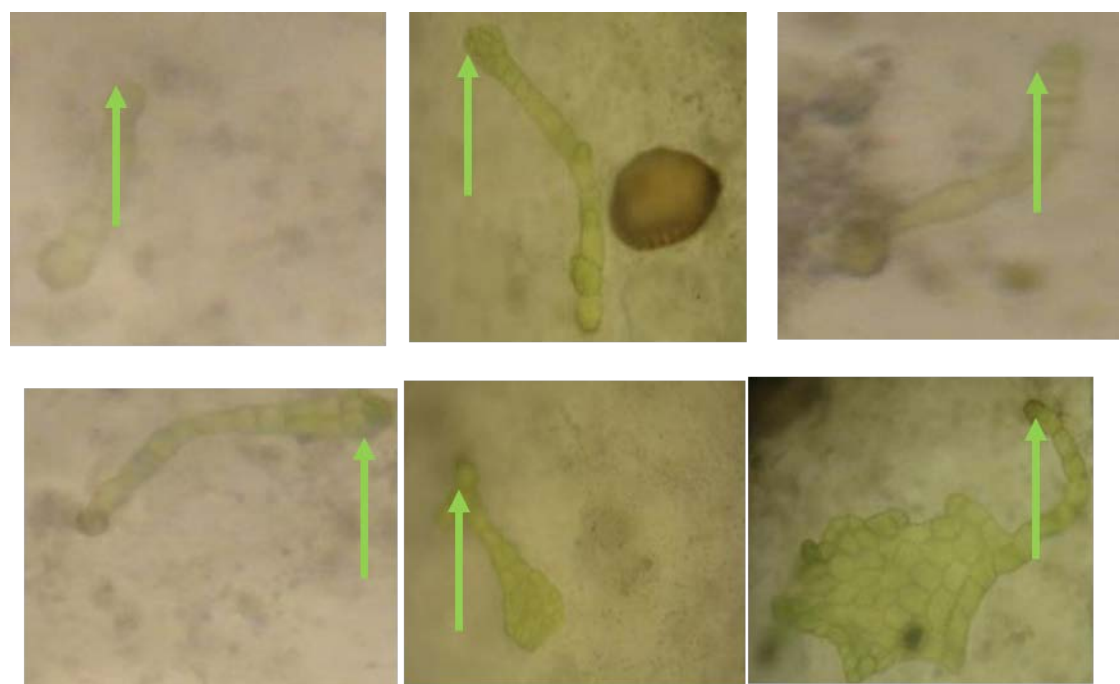

Plate 2. Various stages of spatulate development showing apical regions (arrowed)

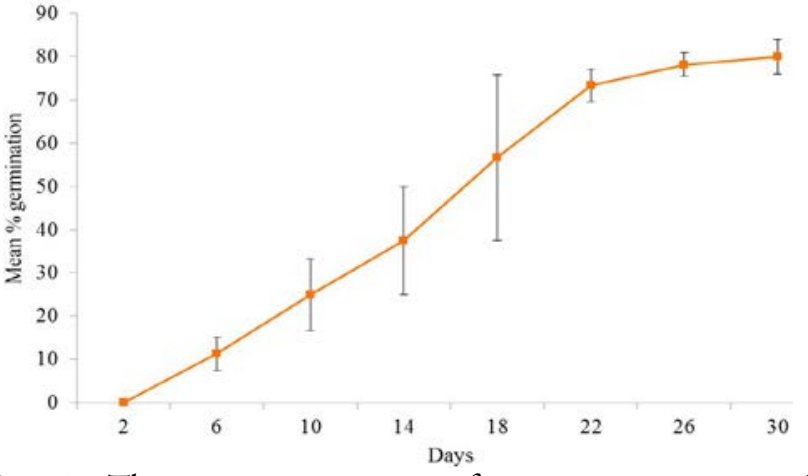

Fig. 1. The mean percentage of spore germination of A. capillus-veneris within days

\section{The filamentous stage (Plate $1 c-f$ )}

The spores first swelled up due to imbibition leading to breaking of the walls after which they started to germinate between 6-10 days of sowing. The first sign of germination was the emergence of a slender, uniseriate, elongated, colourless filamentous rhizoid while the first prothallial cell which was green in colour grown perpendicular to the rhizoid. The prothallial cells started increasing in number from 1-6 cells caused by anticlinal divisions. This is vittariatype of spore germination.

\section{The spatulate stage (Plate 2)}

The filament divided its apical cell and underwent oblique longitudinal divisions that produced daughter apical cells. Division continued in two or more planes which resulted in the formation of a narrow plate that further developed into a spatulate plate. Formation of antheridium started at this stage of development. After a period of 16-26 days after germination, these spatulate gametophytes by longitudinal development of the apex produced the precordate prothallus.

\section{The heart / cordate stage (Plate $3 a-c$ )}

This stage formed through rapid cell divisions. An apical notch which was the meristematic zone formed in the early stages giving rise to the heart-shaped gametophyte. The notch gradually became deeper and the prothallial wings 
560

wider. This took place between 27-60 days. Some outgrowths (archegonia and antheridia) were developed around the notch areas at early stage of this period. The gametophytes were cordate in shape, possessing 12-16 rhizoids; both archegonia and antheridia were found on each gametophyte shows the evidence of being homosporous fern.

This type of gametophyte growth and development is called Drynaria type.

The sporophytic stage (Plate $3 d$ )

Formation of the first sporophytic leaf (fernlet) was observed 90 days from spore sowing.

\section{Growth experiment (Plate $4 a-g$ )}

Leaflet number

At two weeks of growth, two leaflets were observed while three, six and twelve leaflets were observed after four, six and eight weeks respectively (Fig. 2). At ten weeks, fourteen leaflets were observed and sixteen leaflets were seen after twelve weeks of growth.
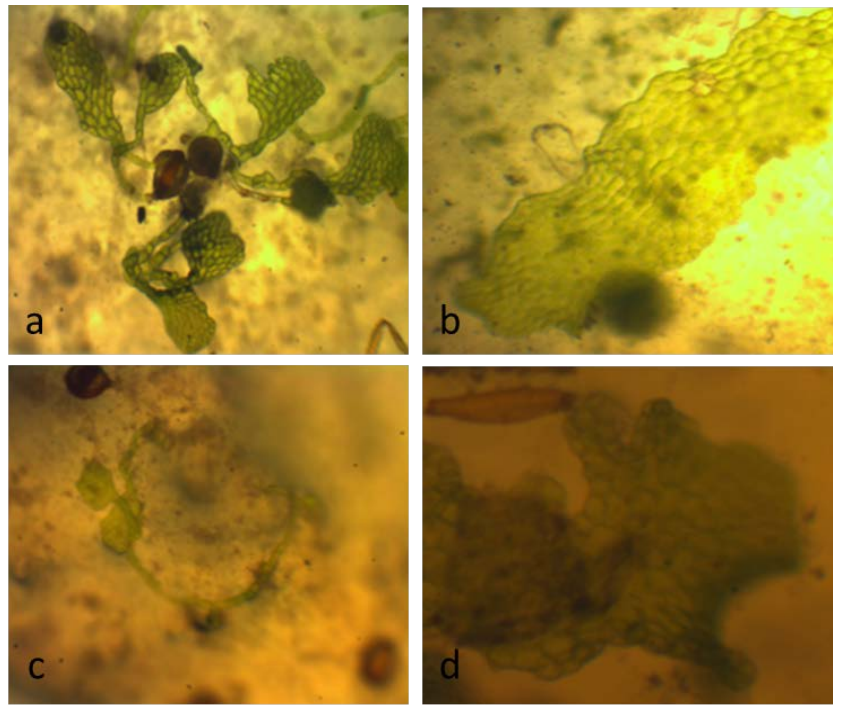

$\times 400$

Plate 3. Spatulate and heart-shaped prothallial developments; a $\&$ b: spatulate stages; c: heart-shaped stage; d: Initiation of the first sporophytic leaflet

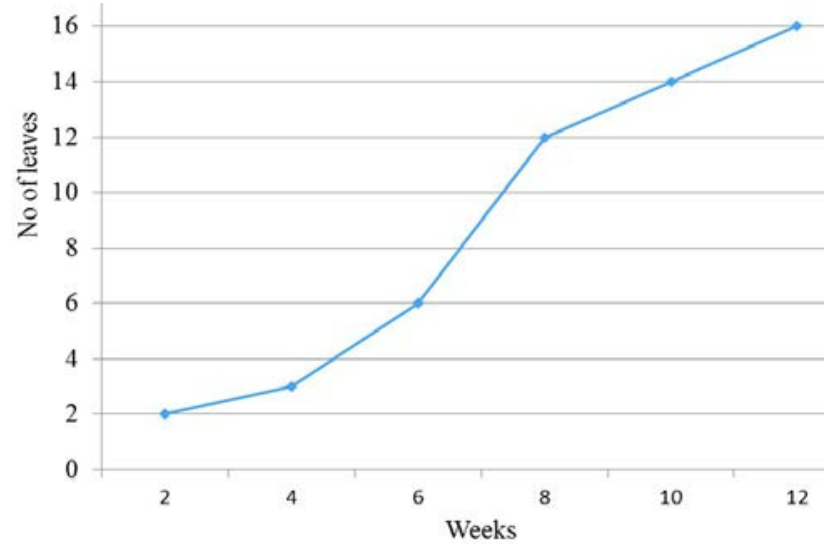

Fig. 2. The number of leaves in fernlets of A. capillus-veneris from week 2 to week 12 of growth

\section{Height of sporophyte}

Plant height increased to $0.50 \mathrm{~cm}$ after two weeks of growth. After four weeks of growth, plant height measured $0.70 \mathrm{~cm}$. It measured $1.90 \mathrm{~cm}, 2.30 \mathrm{~cm}, 2.50 \mathrm{~cm}$ and 2.60 $\mathrm{cm}$ after six, eight, ten and $12^{\text {th }}$ weeks of growth (Fig. 3).

\section{Discussion}

The continuity and distribution of fern species are enhanced by spore production, viability and dispersal. Spore germination of $A$. capillus-veneris on modified Moores medium started between 6-10 days. Once imbibed, the spore coat ruptured, followed first by the emergence of rhizoid, then a greenish filamentous gamentagia and greenish heart- shaped prothallus. This observation was also made by Oloyede et al. (2011) who studied Cyclosorus afer and Hansa et al. (2012) who worked on Pteris vittata. The spore germination of $A$. capillus-veneris is of the "Vittaria

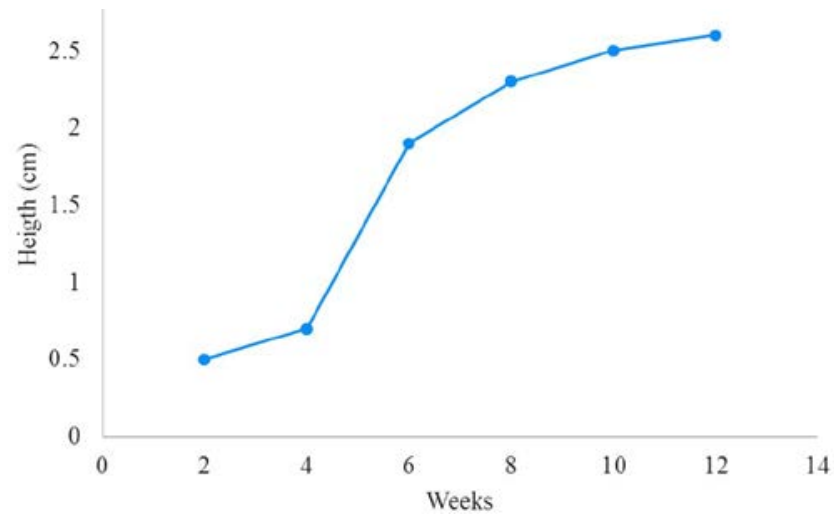

Fig. 3. The heights of $A$. capillus-veneris from week 2 to week 12 of growth
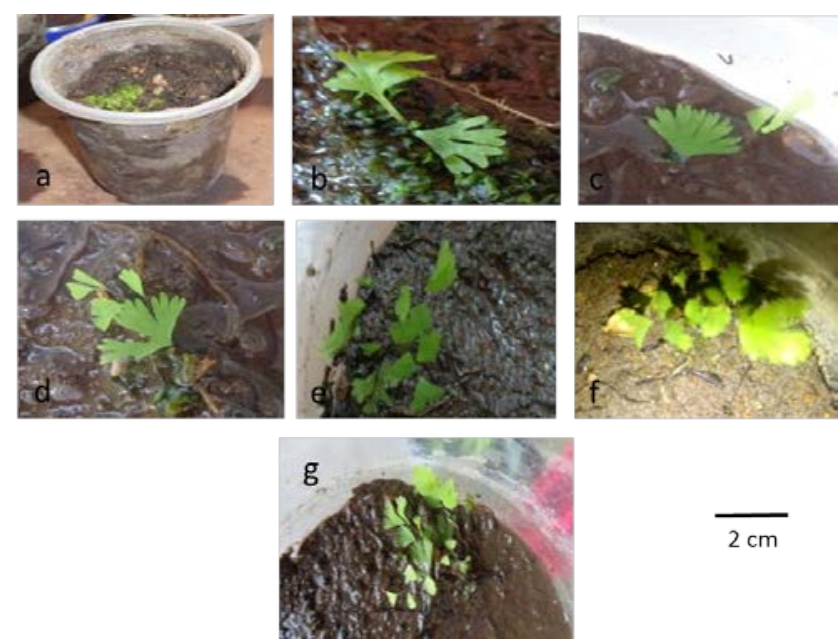

Plate 4. Increase in the number of leaflets of the fernlets; a: one leaflet sporophytic stage transferred from nutrient medium to the garden soil; b: 2-leaflet sporophyte, 2 weeks after the transfer; c: 3-leaflet sporophyte, 4 weeks after the transfer; d: 6leaflet sporophyte, 6 weeks after the transfer; e: 12-leaflet sporophyte, 8 weeks after the transfer; f: 14-leaflet sporophyte, 10 weeks after the transfer; g: 16-leaflet sporophyte, 12 weeks after the transfer 
model' because cell division in the spores produced prothallial and rhizoidal cell (Raghavan, 1989). This model is the most common type in homosporous ferns as observed in Polystichum polyblepharum, Cyclosorus afer and Pteris vittata (Oloyede et al., 2011; Hansa et al., 2012; Migliaro et al., 2012). This pattern of gametophyte development is purely 'Drynaria type' because adult gametophytes are cordate/heart shaped (Nayar and Kaur, 1969). Gamentagia development is of the leptosporangiate type because antheridia are formed from the early development stages of the prothallus as found in Drynaria rooosii (Yang et al., 2009). Prothallus formation and its subsequent development involved the re-orientation of the cell plate which resulted from the apical cells and followed by its cell division. This is similar to the results reported by Verma (2003), Ganguly and Mukhopadhyay (2005) as well as Sara and Manickam (2007). Cell division and expansion of the filamentous stage (one-dimensional gametophyte) gave rise to the spatulate stage (two-dimensional gametophytes). The mature, two-dimensional fern gametophytes have many essential structural attributes similar to some of the terrestrial autotrophs. For example, the green prothallial surface serves as a photosynthetic solar panel (Racassen, 2001). Rhizoids are analogous to root/root hairs as they perform the function of absorption and anchorage to the substrate. Cupitt et al. (2001) who worked on Angiopteris evecta observed that the pattern of spore germination in various media compositions appears to reflect the need for low concentrations of mineral nutrients. Khoo and Thomas (1980) also reported that high mineral salt concentrations tend to retard spore germination and sporophyte formation in Adiantum raddianum cv Tassel. Spores are analogous to seeds and they contain all the required nutrients for early growth, hence the requirement of low nutrient media during initial stages of spore germination, growth and development were highly encouraged.

This study has shown that the cultivation of $A$. capillusveneris from spores using modified Moores nutrient which contains low concentration of macro and micro elements is feasible. Hence, this shows that mineral nutrition and high humidity are important factors in the germination of spores and subsequent gametophyte growth and developments. Viviani (2008) initiated gametophytes from spores of Polypodium lepidopteris sown in mineral nutrient but observed no growth in those sown on sand. The gametophyte growth from spores of $A$. capillus-veneris was observed over a thirty-day period but no growth was observed in the control in which water was used instead of nutrients. The gametophytes were green in colour, indicating their photosynthetic capability. Different stages of initial growth and development observed in this fern species are filamentous, spatulate and the heart-shaped stages before the development of gametophytes. There is an unusually long delay in germination of the spores under natural environmental conditions leading to being endangered, rear, scarce and threatened. Therefore, there is need for a protocol to be followed in raising its fernlets massively and rapidly within a short time. This was achieved using modified Moores medium with agar inside four Petridishes, as spores started germinating within six days.

\section{Conclusions}

In conclusion, the results have shown that freshly collected spores of Adiantum capillus-veneris are viable and have the capacity to germinate. Consequently, $A$. capillusveneris can be raised from the spores on demand most especially for conservation purposes.

\section{References}

Ayisire B, Akinro L, Amoo S (2009). Seed germination and in vitro propagation of Piliostigma thonningii - an important medicinal plant. African Journal of Biotechnology 8:401-404.

Banks J (1999). Gametophyte development in Ferns. Annual Review of Plant Physiology and Plant Molecular Biology 50:163-186.

Baskaran X, Jeyachandran R (2012). In vitro spore germination and gametophyte growth assessment of a critically endangered fern: Pteris tripartita Sw. Gayathri. Teknological 1(1):4-9.

Chang H, Agrawal D, Kuo C, Wen J, Chen C, Tsay H (2007). In vitro culture of Drynaria fortunei, a fern species source of Chinese medicine "Gu-Sui-Bu". In Vitro Cell Developmental Biology of Plants 43:133139.

Cullina W (2008). Native ferns, moss, and grasses: from emerald carpet to amber wave. Serene and Sensuous Plants for the Garden.

Cupitt D, Bhatia P, Ashwath N (2001). In vitro propagation of Angiopteris evecta usingspores. Biotropia 16:1-9.

Deberg P (1994). In vitro culture of ornamentals. In: Vasil IK, Thorpe TA (Eds). PlantCell and Tissue Culture. Kluwer Academic Publishers. TheNetherlands pp 561-573.

Dyer A (1979). The culture of fern gametophytes for experimental investigation. The experimental biology of ferns. Academic Press, London pp 253-305.

Fahimeh S, Nazi M, Mazooji A (2011). Spore morphology of Pteridaceae in Iran. Australian Journal of Basic and Applied Sciences 5(10):1154 1156.

Federal Environmental Protection Agency (FEPA) (1991). Guidelines and Standards for Environmental Pollution Control in Nigeria.

Federal Republic of Nigeria (FRN), FNBR (2010). Federal Republic of Nigeria, Fourth National Biodiversity Report.

Ganguly G, Mukhopadhyay R (2005). In vitro study on gametophyte development of Hypolepis alpine (Bl.) Hook. Phytomorphology 55(34):179-184.

Hansa J, Chakraborty B, Amin B, Sandip L, Behera K, Amiya K (2013). Pteris vittata propagation through different exposure of chromium concentration:an experiment to comprehend phytoremediation properties. Advances in Bioresearch 4(1):43-49.

The International Union for Conservation of Nature (IUCN) (2013). IUCN Red List (August, 2013). Retrieved on 24 September 2017 from http://www.iucnredlist.org/.

Jagadish P, Joshi S (2013). In vitro morphogenesis of Colysis latiloba (Ching.) Ching. International Journal of Scientific \& Technology Research 2(3):513-523. 
562

Jones D (1998). Encyclopaedia of ferns: an introduction to ferns, their structure, biology, economic importance, cultivation and propagation. Port Melbourne Lothian 13:1440.

Kato Y (1969). Physiological and morphogenetic studies of fern gametophytes in aseptic culture of callus tissues from dark-cultured Pteris vittata. Botanical Gazette 124:413-416.

Khoo S, Thomas M (1980). Studies on the germination of fern spores. The Plant Propagator 26:11-15.

Lansdown RV, Bilz M (2013). Adiantum capillus-veneris. The International Union for Conservation of Nature (IUCN) Red List of Threatened Species. Version 2014.3.

Mazumder B, Choudhury M, Mazumder P (2010). Effect of growth regulators on in vitro propagation of Bolbitis costata (Wall ex. Hook.) C. Chr. Assam University Journal of Science \& Technology, Biological and Environmental Sciences 5:23-33.

Migiaro G, Gabriel G, Galan W (2012). Gametophyte development and reproduction of the Asian fern Polystichum polyblepharum. (Roem. ex Kunzie)C.Presl (Dryopteridaceae, Polypodiopsida). Plant Biosystems 146(2):368-373.

Nayar B, Kaur S (1969). Types of prothallial development in homosporous ferns. Phytomorphology 19:179-188.

Oloyede F, Odu E (2011). Taxonomic evaluation of Homosporous leptosporangiate ferns (Pteridophytes) in Southwestern Nigeria. International Journal of Current Research 2(2):9-17.

Oloyede F, Aponjolosun B, Ogunwole A (2011). Reproductive potentials of a tropical fern Cyclosorus afer (Christ.) Ching (Thelypteridaceae: Pteridophyte) at Obafemi Awolowo University, Ile- Ife, Nigeria. Ife Journal of Science 13:1-5.

Racasen R (2001). Early development in fern gametophytes: interpreting the transistion to prothallial architecture in terms of coordinated photosynthate production and osmotic ion uptake. Annals of Botany 89:227-240.
Raghavan V (1989). Developmental biology of fern gametophytes Cambridge: Cambridge University Press.

Rajkumar S, Kumar S, Guntum R, Kumar S (2010). Plant species biology. Department ofSt Andrew's College (PG) IJBT.

Ruchi S, Jyoti S, Scandip K, Khare P (2008). In vitro studies on development of gametophyte, sex- ontogeny and reproductive biology of a threatened fern,Microsorium punctatum (L.) Copel. Indian Journal of Biotechnology 7:266-269.

Sara S, Manickam V (2007). In vitro developmental ontogeny and life cycle of a rare fern Thelypteris confluens (Thunb.) Morton. Indian Journal of Biotechnology 6:372-380.

Verma $S$ (2003). Some aspects of reproductive biology of gametophyte generation of homosporous ferns. Pteridology in New Millennium, Kluwer Academic Publishers. Netherland pp 455-484.

Verma S, Kaur A, Selvan P (2000). Experimental studies on the gametophyte generation of homosporous ferns-IH sexuality, gametangial sequence and mating system in some species of Pteris. Indian Fern Journal 17:136-174.

Victor B, Maridass M, Ramesh U, Prabhu J (2003). Antibacterial activity of essential oils from the leaves of Adiantum capillus - veneris Linn. Malaysian Journal ofSciences 22:65-66.

Viviani D, Randi A (2008). Effects of $\mathrm{pH}$, temperature and light intensity on spore germination and growth analysis of young sporophytes of Polypodium lepidopterist (Pteridophyta, Polypodiaceae). Rodriguesia 59(4):751-760.

Yaadwinder S (2010). In-vitro micro propagation of medicinal plants by tissue culture. The Plymouth Student Scientist 4(1):432-449. 